ORIGINAL ARTICLE

\title{
Phenolic compounds from Virola venosa (Myristicaceae) and evaluation of their antioxidant and enzyme inhibition potential
}

Kamila Rangel Primo FERNANDES ${ }^{1,2}$, Paulo Senna BITTERCOURT ${ }^{2}$, Afonso Duarte Leão de SOUZA², Antonia Queiroz Lima de SOUZA², Felipe Moura Araújo da SILVA², Emerson Silva LIMA3, Leonard Domingo Rosales $\mathrm{ACHO}^{3}$, Rita de Cássia Saraiva NUNOMURA², Ana Frazão TEIXEIRA, ${ }^{1, \dagger}$ Hector Henrique Ferreira KOOLEN ${ }^{1^{*}}$

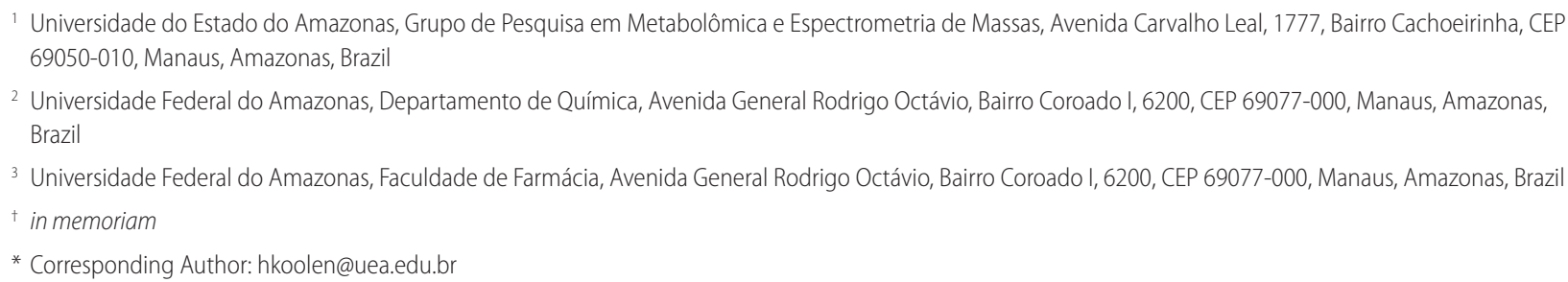

\section{ABSTRACT}

Virola venosa, popularly known in Brazil as ucuuba-da-mata, occurs naturally in the Amazon region and has potential to provide useful natural compounds, as already known for other Virola species. Therefore, the objective of this study was to determine the chemical composition of bark and leaf extracts of $V$. venosa, and to test the antioxidant capacity and $\alpha$-glucosidase inhibition potential of their compounds. Polar extracts showed to be more active in both assays, therefore a bioactivity-guided fractionation was performed to identify the compounds that were responsible for the recorded activities. Using a combination of LC-MS/MS analysis and isolation with NMR identification, eight phenolic compounds were identified. Assays with pure compounds of the active fraction revealed that ferulic acid was the main contributor compound to the observed bioactivity in the crude extracts.

KEYWORDS: $\alpha$-glucosidase inhibition, antioxidant compounds, ferulic acid, Amazon

\section{Compostos fenólicos de Virola venosa (Myristicaceae) e avaliação de seu potencial antioxidante e de inibição enzimática}

\section{RESUMO}

Virola venosa, popularmente conhecida como ucuuba-da-mata, ocorre naturalmente na região amazônica e tem potencial para fornecer compostos naturais úteis, como já foi mostrado para outras espécies de Virola. Por isso, o objetivo deste estudo foi determinar a composição química dos extratos do tronco e das folhas de $V$. venosa e os possíveis potenciais antioxidantes e de inibição contra $\alpha$-glucosidase de seus compostos. Os extratos polares mostraram-se mais ativos em ambos os testes, portanto, um fracionamento guiado por bioatividade foi realizado para designar os compostos responsáveis pelas atividades registradas. Através da combinação de análise CL-EM/EM e isolamento com identificação por RMN, foram identificados oito compostos fenólicos. Testes com os compostos puros principais das fraçôes mais ativas indicaram o ácido ferúlico como o principal contribuinte das atividades biológicas observadas para os extratos brutos, e, consequentemente, o princípio ativo principal de $V$. venosa.

PALAVRAS-CHAVE: inibição de $\alpha$-glucosidase, compostos antioxidantes, ácido ferúlico, Amazônia

CITE AS: Fernandes, K.R.P.; Bittercourt, P.S.; Souza, A.D.L.de; Souza, A.Q.L.de; Silva, F.M.A.da; Lima, E.S.; Acho, L.D.R.; Nunomura, R. de C.S.; Teixeira, A.F. Koolen, H.H.F. 2018. Phenolic compounds from Virola venosa (Myristicaceae) and evaluation of their antioxidant and enzyme inhibition potential. Acta Amazonica 49: 48-53. 


\section{INTRODUCTION}

The Myristicaceae, or nutmeg family, is an old group containing 500 different species native to tropical rainforest environments, which are distributed in 18 genera (Rodrigues 1980). Among these, Virola species have been studied over the past years due to its folk medicinal applications in the treatment of microbial infections, rheumatism, asthma, hemorrhoids, tumors and inflammatory diseases (Barata et al. 2000; Stecanella et al. 2012; Coutinho et al. 2017).

Despite the description of $\beta$-carboline alkaloids (Kawanishi et al. 1985), diarylpropanoids (Gottlieb et al. 1979), and phenolic compounds such as chromones, flavonoids, lignans, and neolignans (Lopes et al. 1999; Valderrama 2000, Pereira et al. 2016; Veiga et al. 2017), several Virola species remain chemically unstudied. Among the 93 known species of this genus (Riba-Hernández et al. 2014), Virola venosa (Poepp Ex. A. DC) Warb. (known as ucuuba-da-mata in Brazil) lacks information about its chemical and pharmacological potentials. So far, lignoids and phenolic compounds have been described in restricted studies with the flowers and wood of this tree species (Braz-Filho et al. 1977; Kato et al. 1992).

Therefore, considering the lack of knowledge on the chemical composition and biological potentials of other parts of $V$. venosa, this study aimed to perform a phytochemical study of the leaf and bark extracts of $V$. venosa, aiming at the identification of antioxidant and $\alpha$-glucosidase inhibitory compounds.

\section{MATERIAL AND METHODS}

\section{Reagents}

The chemical reagents for in vitro biological assays used in this work were purchased from Sigma-Aldrich ${ }^{\mathrm{TM}}$. The organic solvents ( $n$-hexane, ethanol, ethyl acetate, and methanol) employed for the chemical analyses were of high-performance liquid chromatography-grade $\left(\right.$ Tedia $\left.^{\mathrm{TM}}\right)$. Ultrapure water (18.2 M $2 . \mathrm{cm})$ was obtained from a Milli-Q purifier through a gradient system (Millipore ${ }^{\mathrm{TM}}$ ).

\section{Plant collection}

Trunk bark (400 g) and young leaves (987 g) from a single specimen of Virola venosa were collected in July 2013 in a forest fragment reserve within the grounds of the Federal University of Amazonas (UFAM) (0360'58"S, 5958'45"W), in the city of Manaus, Amazonas state, Brazil. The fertile plant material was identified by Dr. Antonio C. Weber of the UFAM Herbarium, where a voucher specimen was deposited (HUA$\mathrm{n}^{\circ}$ 010001). The Institutp Chico Mendes para Conservação da Biodiversidade - ICMBio provided authorization (\# 51662-3) from the Brazilian Ministry of Environment for the plant collection. This work was performed according to the special authorization for access to genetic resources in Brazil (\# 010240/2013-6), issued by Conselho Nacional de
Desenvolvimento Científico e Tecnológico - CNPq/ Ministério da Ciência, Tecnologia, Inovaçôes e Comunicaçôes - MCTIC.

\section{Chemical extraction}

The collected material was submitted to a sequential maceration procedure at room temperature performed with $n$-hexane (leaf extract, HLE and bark extract, THE), ethyl acetate (leaf extract, ALE and bark extract, ATE), and methanol (leaf extract, MLE and bark extract, MTE) (3 L and $3 \mathrm{X}$ for each solvent). This yielded the respective solvent extract of each plant part (Table 1). To select the most promising extracts and further fractions for compound purifications, the total phenolic content (TPC), antioxidant capacity (AC), and $\alpha$-glucosidase inhibition assays were performed (bioactivityguided fractionation).

\section{Total phenolic content assay}

The TPC was measured using the Folin-Ciocalteu colorimetric method following Guilhon-Simplicio et al. (2017). Dried extracts and fractions were dissolved in ethanol at $10 \mathrm{mg}$ $\mathrm{mL}^{-1}$. Each solution $(1 \mathrm{~mL})$ was transferred to a test tube, where distilled water $(400 \mu \mathrm{L})$ and the Folin-Ciocalteau reagent $(160 \mu \mathrm{L})$ were added. After homogenization, 10.6\% aqueous sodium carbonate $\left(\mathrm{Na}_{2} \mathrm{CO}_{3}\right)(4 \mathrm{~mL})$ was added. After incubation for $3 \mathrm{~min}$, the absorbance was measured at $740 \mathrm{~nm}$ in a Ultrospec 2000 spectrophotometer (Amersham Pharmacia Biotech $\left.{ }^{\mathrm{TM}}\right)$. The total polyphenol content was expressed in milligrams (mg) of equivalents of gallic acid per gram $(\mathrm{g})$ of extract $\left(\mathrm{mg} \mathrm{GAE} \mathrm{g}^{-1}\right)$.

\section{Antioxidant capacity assay}

The AC was determined for extracts and fractions through the 2,2-diphenyl-1-picrylhydrazyl radical (DPPH•) assay in triplicate and in the same spectrophotometer according to Souza et al. (2016). The consumption of DPPH• was monitored by measuring the absorbance at $492 \mathrm{~nm}$. For this assay, the percentage of inhibition was calculated according to the equation: percentage $(\%)$ of inhibition $=100-$ (absorbance / average absorbance of control) $\times 100$, and as half maximal efficient concentration $\left(\mathrm{EC}_{50}\right)$ in micrograms per milliliter $\left(\mu \mathrm{g} \mathrm{mL} L^{-1}\right)$. The positive control was gallic acid $\left(\mathrm{EC}_{50} 3.5 \mu \mathrm{g} \mathrm{mL} \mathrm{m}^{-1}\right)$.

\section{Enzyme inhibition assay}

For the $\alpha$-glucosidase inhibition assay (Iauk et al. 2014), initially a maltose solution $(12 \mathrm{~g}$ of maltose in $300 \mathrm{~mL}$ of 50 $\mathrm{mM}$ sodium acetate buffer) was prepared. Enzyme solution $\left(0.1 \mathrm{mg} \mathrm{mL}^{-1}\right)$, dianisidine color reagent (DIAN) (1 tablet in $25 \mathrm{~mL}$ ), and peroxidase-glucose oxidase (PGO) system-color reagent (1 capsule in $100 \mathrm{~mL}$ ) were prepared in ice-cold distilled water. Samples and controls were added to the maltose solution and left to equilibrate for 5 minutes at $37^{\circ} \mathrm{C}$. The addition of $\alpha$-glucosidase solution started the reaction. After 30 minutes of incubation at $37^{\circ} \mathrm{C}$, the reaction was stopped by adding a 
Table 1. Total phenolic content, antioxidant capacity, and enzyme inhibition potential of crude bark and leaf extracts, selected fractions, and isolated compounds from Virola venosa.

\begin{tabular}{|c|c|c|c|c|c|}
\hline Samples & $\begin{array}{c}\text { TPC }^{a} \\
\left(\mathrm{GAE} \mathrm{g}^{-1}\right) \\
\end{array}$ & $\begin{array}{c}\mathrm{DPPH}^{\mathrm{b}} \\
(\%)\end{array}$ & 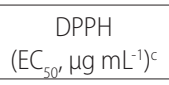 & $\begin{array}{c}\text { a-glucosidase } \\
(\%)\end{array}$ & $\begin{array}{c}\text { a-glucosidase } \\
\left(\mathrm{EC}_{50^{\prime}} \mathrm{\mu g} \mathrm{mL}^{-1} \text { and } \mathrm{mM}\right)^{\mathrm{e}}\end{array}$ \\
\hline HLE & $4.28 \pm 0.22$ & na & na & na & \\
\hline HTE & $5.36 \pm 0.27$ & na & na & na & \\
\hline ALE & $6.14 \pm 0.41$ & na & na & $76.1 \pm 1.27$ & $50.2 \pm 2.47$ \\
\hline ATE & $4.98 \pm 0.29$ & $88.3 \pm 1.15$ & $34.7 \pm 2.31$ & $98.4 \pm 2.04$ & $1.92 \pm 0.04$ \\
\hline MTE & $7.13 \pm 0.35$ & $99.4 \pm 2.03$ & $13.4 \pm 1.12$ & $99.8 \pm 2.11$ & $1.64 \pm 0.05$ \\
\hline MLE & $9.74 \pm 0.58$ & $87.1 \pm 1.88$ & $30.1 \pm 1.99$ & $99.9 \pm 1.99$ & $1.93 \pm 0.09$ \\
\hline MTFr.2 & $22.13 \pm 1.55$ & $99.9 \pm 1.93$ & $15.1 \pm 1.20$ & $79.2 \pm 1.45$ & $42.0 \pm 2.67$ \\
\hline MTFr.3 & $34.65 \pm 1.74$ & $99.3 \pm 1.90$ & $18.6 \pm 1.20$ & $96.6 \pm 2.00$ & $15.0 \pm 1.06$ \\
\hline MTFr.4 & $17.10 \pm 1.11$ & $86.7 \pm 1.47$ & $27.1 \pm 1.38$ & $98.5 \pm 1.85$ & $12.3 \pm 1.31$ \\
\hline MLFr.7 & $41.80 \pm 2.09$ & $86.2 \pm 1.99$ & $29.1 \pm 1.27$ & $99.9 \pm 2.01$ & $11.0 \pm 0.97$ \\
\hline Compound 2 & & nd & & na & \\
\hline Compound 4 & & nd & & $99.9 \pm 1.88$ & $1.63 \pm 0.11$ \\
\hline Compound 5 & & nd & & na & \\
\hline Compound 6 & & nd & & na & \\
\hline Gallic acidf & & $95.6 \pm 0.85$ & $3.25 \pm 0.25$ & nd & \\
\hline Acarbose $^{g}$ & & nd & & $99.9 \pm 1.35$ & $6.05 \pm 0.06$ \\
\hline
\end{tabular}

a Total phenolic content expressed as gallic acid equivalents (GAE) per gram of crude extract or fraction.

${ }^{\mathrm{b}}$ Antioxidant capacity (AC) expressed in \% of inhibition of the 2,2-diphenyl-1-picrylhydrazyl radical (DPPH)

cAntioxidant capacity (AC) expressed as $\mu \mathrm{g} \mathrm{mL}^{-1}\left(\mathrm{EC}_{50}\right)$ of crude extract or fraction

${ }^{d}$ Enzyme inhibition capacity expressed in $\%$ of inhibition of a-glucosidase

eEnzyme inhibition capacity expressed as $\mu \mathrm{g} \mathrm{mL}^{-1}\left(\mathrm{EC}_{50}\right)$ of crude extract or fraction and as $\mathrm{mM}$ for pure compounds

${ }^{f}$ Positive control for the antioxidant assay.

${ }^{g}$ Positive control for the enzyme inhibition assay

na $=$ not active; nd $=$ not determined

solution of perchloric acid. The supernatant of the tube from the first step was mixed with DIAN and PGO and incubated at $37^{\circ} \mathrm{C}$ for $30 \mathrm{~min}$. Acarbose was used as positive control.

All assays were performed in triplicate with extracts, fractions, and pure compounds. The results were expressed with its corresponding $\%$ and $\mathrm{EC}_{50}$ of inhibition mean \pm standard deviation (SD), and $\mathrm{mM}$ for pure compounds.

\section{Bioactivity-guided fractionation and purification}

The methanol extracts of the bark (MTE, $4.71 \mathrm{~g}$ ) and of the leaves (MLE, $11.7 \mathrm{~g}$ ) were selected for the first fractionation step due to their recorded biological activities. A part of MTE $(2.0 \mathrm{~g})$ was subjected to a silica gel column chromatography, eluted with gradient systems of $n$-hexane-ethyl acetate (90:10 to $10: 90)$ and ethyl acetate-methanol (100:0 to $10: 90)$. The eluted fractions were pharmacologically assayed and chemically evaluated by thin-layer chromatography (TLC). A portion of the crude extract MLE (3.0 g) was fractionated over silica gel column chromatography, eluted with gradient systems of n-hexane-ethyl acetate (90:10 to 10:90), ethyl acetate-acetone (100:0 to $10: 90)$, and acetone-methanol (90:10 to 0:100). The obtained fractions were compared by TLC and submitted to TPC, AC, and $\alpha$-glucosidase inhibition assays. Semipreparative high-performance liquid chromatography (HPLC) fractionation with an isocratic elution (85\% methanol) at a flow rate of $8.0 \mathrm{~mL} \mathrm{~min}^{-1}$ was performed with the selected fractions for the compound purification.

\section{Chemical identification}

Liquid chromatography coupled to tandem mass spectrometry analysis (LC-MS/MS) was performed according to Bataglion et al. (2015) in order to access the chemical composition of fractions MTFr.3-4 and MLFr.7. Collisional induced dissociation (CID) fragmentation patterns were interpreted in comparison with published data (Souza et al. 2016). Nuclear magnetic resonance spectroscopy (NMR) analysis was performed to confirm the chemical structures of the isolated compounds. NMR data were acquired in methanol- $d_{4}$ for ${ }^{1} \mathrm{H}$ and ${ }^{13} \mathrm{C}$ nucleus at 500 and $125 \mathrm{MHz}$, respectively. The obtained spectra were compared with the literature (Ivanov et al. 2011; Koolen et al. 2012; Forino et al. 2016).

\section{RESULTS}

The preliminary TPC evaluation of the extracts indicated that MTE, ATE and MLE had a high phenolic content, and were the most active in the AC and enzyme inhibitory tests (Table 1). Bioactivity-guided fractionation with ATE resulted in non-active fractions, and therefore these samples were discontinued from our screening program. Fractionations with MTE and MLE resulted in six (MTFr.1 to MTFr.6) and seven (MLFr.1 to MLFr.7) fractions, respectively. Fraction MTFr.2 (ethyl acetate 100\%) displayed a high AC $\left(\mathrm{EC}_{50}=\right.$ $\left.15.1 \pm 1.20 \mu \mathrm{g} \mathrm{mL}^{-1}\right)$. Nevertheless, the enzyme inhibition of this fraction was lower compared to other samples. Thus, 
fractions MTFr.3 (ethyl acetate 1:1 methanol, v/v) and MTFr.4 (ethyl acetate 2:8 methanol, v/v), which had AC with $\mathrm{EC}_{50}=18.6 \pm 1.20$, and $27.1 \pm 1.38$, respectively, for the $\mathrm{DPPH}$ assay, and $\alpha$-glucosidase inhibition with $\mathrm{EC}_{50}=15.0$ \pm 1.06 , and $12.3 \pm 1.31 \mu \mathrm{g} \mathrm{mL}^{-1}$, respectively, were selected for purification. Based on the assay results and TLC analysis, fractions MTFr.3 and MTFr.4 were pooled (MTFr.3-4, 81.3 $\mathrm{mg}$ ) for further purification and chemical characterization. From the leaf extract fractions, only MLFr.7 $(50.0 \mathrm{mg})$ was selected (methanol 100\%). This fraction displayed moderate $\mathrm{AC}\left(\mathrm{EC}_{50}=29.1 \mu \mathrm{g} \mathrm{mL}^{-1}\right)$ and a high enzyme inhibition $\left(\mathrm{EC}_{50}\right.$ $=11.0 \pm 0.97 \mu \mathrm{g} \mathrm{mL}-1)$.

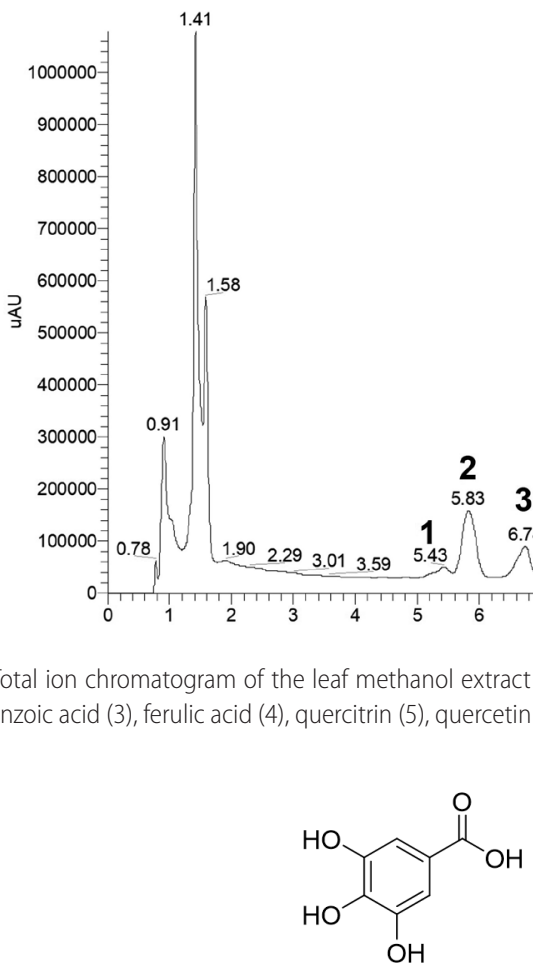

1<smiles>O=C(O)/C=C/c1ccc(O)cc1</smiles>

2<smiles>[R]c1c(-c2ccc(O)c(O)c2)oc2cc(O)cc(O)c2c1=O</smiles><smiles>O=c1c(O)c(-c2ccc(O)cc2)oc2cc(O)cc(O)c12</smiles>
4-hydroxybenzoic acid (3), ferulic acid (4), quercitrin (5), quercetin (6), kaempferol (7), and ( \pm )-catechin (8).<smiles>COc1cc(/C=C/C(=O)O)ccc1O</smiles>

The LC-MS/MS analysis of MLFr.7 (Figure 1) and MTFr.3-4 displayed similar chemical profiles, the former showing the most complex composition. Eight compounds were identified directly in the fractions as: acid gallic (1), p-coumaric acid (2), 4-hydroxybenzoic acid (3), ferulic acid (4), quercitrin (5), quercetin (6), kaempferol (7), and $( \pm)$-catechin (8). Compounds 2 (6.2 mg), $\mathbf{4}(4.3 \mathrm{mg}), \mathbf{5}$ (11.8 $\mathrm{mg})$, and $\mathbf{6}(18.1 \mathrm{mg})$ for MLFr.7 and $\mathbf{5}(17.3 \mathrm{mg})$ and $\mathbf{6}$ $(13.8 \mathrm{mg}$ ) for MTFr.3 + MTFr.4 (Figure 2) were successfully purified by semi-preparative HPLC, and their structures were confirmed by NMR. Among the isolated compounds, ferulic acid (4) was the unique compound with $\alpha$-glucosidase inhibitory activity $(1.63 \pm 0.11 \mathrm{mM})$.

Figure 1. Total ion chromatogram of the leaf methanol extract fraction 7 (MLFr.7) from Virola venosa obtained by LC-MS/MS. Acid gallic (1), p-coumaric acid (2), 


\section{DISCUSSION}

The genus Virola is well known as a prolific source of phenolic compounds, mainly lignans, neolignans, hydroxycinnamic acid derivatives, and flavonoids (Rezende et al. 2002). These compounds are present in extracts obtained with highpolarity solvents, which may explain the high AC recorded for our extracts. Lignoids, especially 8-O-4'-neolignans, have shown to possess high AC (Konya et al. 2001). Flavonoids, pterocarpans, chalcones, and hydroxycinnamic acid derivatives are less recurrent, but also with high AC (Valderrama 2000).

Virola venosa showed to be a new source of valuable phenolic compounds (simple phenolic acids, hydroxycinnamic acids, flavonoids, and catechins). Among the identified compounds, ferulic and gallic acids were previously identified and quantified in the resins of $V$. oleifera (Bôa et al. 2015). Quercetin, quercitrin, and catechin were previously identified in $V$. carinata (Orduz et al. 2013), V. sebifera (Bicalho et al. 2012), and $V$. surinamensis (Hiruma-Lima et al. 2009), respectively. Compounds $\mathbf{1}, \mathbf{2}$, and 7 were described here in $V$. venosa for the first time.

Several studies demonstrated that phenolic-like compounds can inhibit $\alpha$-glucosidase and other related enzymes (Adisakwattana et al. 2004). $\alpha$-Glucosidase inhibitors are potential compounds for the treatment of diabetes, once they reduce diet-induced hyperglycemia by inhibiting this intestinal enzyme (Ha et al. 2012). In addition, the isolated compounds were also previously described as being cytotoxic against several cancer cell lines, but presenting low cytotoxicity against normal cell lines (Heleno et al. 2015). Studies of the relation between structural aspects and activity with this type of compounds described the phenol moieties as the keys for the antioxidant and cytotoxic activities (Heleno et al. 2014).

Our results agree with previous phytochemical studies of Virola species, in which phenolic compounds play a central role (Valderrama 2000). The recorded AC in V. venosa confirm the potential of this genus as a promising source of antioxidant compounds (Rezende et al. 2005; Coutinho et al. 2017). The activity-guided fractionation indicated that the compound mainly responsible for the AC and $\alpha$-glycosidase inhibition observed for the crude extracts was ferulic acid (4). Similar results were obtained for antioxidant activity when using ferulic acid as a pure compound (Kanski et al. 2002) and in an analysis of its structural relationship with other hydroxycinnamic acid analogues to inhibit $\alpha$-glycosidase (Adisakwattana et al. 2004).

\section{CONCLUSIONS}

The polar extracts of leaves and bark of and Amazonian species of the genus Virola, V. venosa, showed potential to be a valuable source of phenolic compounds. The methanol extracts were the most active and promising ones. Activity-guided fractionation allowed us to identify eight phenolic compounds from the most active fractions by means of LC-MS/MS and NMR. The antioxidant and $\alpha$-glycosidase inhibitory activities were attributed to the phenolic compounds present in the most active fractions, where ferulic acid (4) was likely the main active compound. We conclude that Virola venosa has potential to be used in further investigations regarding its activity against diseases such as diabetes.

\section{ACKNOWLEDGMENTS}

The authors are grateful to Conselho Nacional de Desenvolvimento Científico e Tecnológico (CNPq), Fundação de Amparo à Pesquisa do Estado do Amazonas (FAPEAM), and to Central de Apoio Multidisciplinar da Universidade Federal do Amazonas (UFAM - CAM).

\section{REFERENCES}

Adisakwattana, S.; Sookkongwaree, K.; Roengsumran, S.; Petsom, A.; Ngamrojnavanich, N.; Chavasiri, W.; Deesamer, S.; Yibchokanun, S. 2004. Structure-activity relationships of trans-cinnamic acid derivatives on $\alpha$-glucosidase inhibition. Bioorganic $\&$ Medicinal Chemistry Letters, 14: 2893-2896.

Barata, L.E.S.; Santos, L.S.; Ferri, P.H.; Phillipson, J.D.; Paine, A.; Croft, S.L. 2000. Anti-leishmanicidal activity of neolignans from Virola species and synthetic analogues. Phytochemistry, 55: 589-595.

Bataglion, G.A.; da Silva, F.M.A.; Eberlin, M.N.; Koolen, H.H.F. 2015. Determination of the phenolic composition from Brazilian tropical fruits by UHPLC-MS/MS. Food Chemistry, 18: 280-287.

Bicalho, K.U.; Terezan, A.P.; Martins, D.C.; Freitas, T.G.; Fernandes, J.B.; das Graças, M.F.; da Silva, F.; Vieira, P.C.; Pagnocca, F.C.; Bueno, O.C. 2012. Evaluation of the toxicity of Virola sebifera crude extracts, fractions and isolated compounds on the nest of leaf-cutting ants. Psyche, 12: 1-7.

Bôa, I.S.F.; Porto, M.L.P.; Pereira, A.C.H.; Ramos, J.P.L.; Sherer, R.; Oliveira, J.P.; et al. 2015. Resin from Virola oleifera protects against radiocontrast-induced nephropathy in mice. Plos One, 10: $1-15$.

Braz-Filho, R.; Gottlieb, O.R.; De Moraes, A.A.; Pedreira, G.; Pinho, S.L.V; Magalhães, M.T.; Ribeiro M.N.S. 1977. The chemistry of Brasilian Myristicaceae. IX. Isoflavonoids from Amazonia species. Lloydia, 40: 236-238.

Coutinho, P.N.; Pereira, B.P; Pereira, A.C.H.; Porto, M.L.; Assis, A.L.E.M.; Destafani, A. C.; Meyrelles, S.S.; et al. 2017. Chronic administration of antioxidant resin from Virola oleifera attenuantes atherogenesis in LDLr mice. Journal of Ethnopharmacology, 206: 65-72.

Forino, M.; Tartaglione, L.; Dell'Aversano, C.; Ciminiello, P. 2016. NMR- based identfication of the phenolic profile of fruits of Lycium barbarum (goji berries). Isolation and structural determination of a novel $N$ - feruloyl tyramine dimer as the most abundant antioxidante polyphenol of goji berries. Food Chemistry, 194: 1254-1259. 
Gottlieb, O.R.; Almeida, M.E.L.; Filho, R.B.; Bulow, M.V.V.; Corrêa, J.J.L.; Maia, J.G.S.; Silva, M.S. 1979. Diarylpropanoids from Iryanthera Polyneura. Phytochemistry, 18: 1015-1016.

Guilhon-Simplicio, F.; Machado, T.M.; do Nascimento, L.F.; Souza, R.S.; Koolen, H.H.F.; da Silva, F.M.A.; et al. 2017. Chemical composition and antioxidant, antinociceptive, and antiinflammatory activities of four Amazonian Byrsonima species. Phytotherapy Research, 31: 1686-1693.

Heleno, S.A.; Ferreira, I.C.F.R.; Calhelha, R.C.; Esteves, A.P., Queiroz, M.J.R.P. 2014. Cytotoxicity of Coprinopsis atramentaria extract, organic acids and their synthesized methylated and glucuronate derivatives. Food Research International, 55: 170-175.

Heleno, S. A.; Martins, A.; Queiroz, M.J.R.P.; Ferreira, I.C.F.R. 2015. Bioactivity of phenolic acids: Metabolites versus parent compounds. Food Chemistry, 173: 501-513.

Ha, T.J.; Lee, J.H.; Le, M.; Lee, B.W.; Kwon, H.S.; Park, C.H.; et al. 2012. Isolation and identification of phenolic compounds from the seeds of Perilla frutescens (L.) and their inhibitory activities against $\alpha$-glucosidase and aldose reductase. Food Chemistry, 135: 1397-1403.

Hiruma-Lima, C.A.; Batista, L.M.; de Almeida, A.B.; Magri, L. de P.; dos Santos, L.C; Vilegas, W.; Brito, A.R.M.S. 2009. Antiulcerogenic action of ethanolic extract of the resin from Virola surinamensis Warb. (Myristicaceae). Journal of Ethopharmacology, 122: 406-409.

Iauk, L.; Acquaviva, R.; Mastrojeni, S.; Amodeo, A.; Pugliese, M.; Ragusa, M.; Loizzo, M.R.; Menichini, F.; Tundis, R. 2014. Antibacterial, antioxidant and hypoglycaemic effects of Thymus capitatus (L.) Hoffmanns. et Link leaves' fractions. Journal of Enzyme Inhibition and Medicinal Chemistry, 17: 1-6.

Ivanov, S.A.; Nomura, K.; Malfanov, I.L.; Sklyar, I.V.; Ptitsyn, R.L. 2011. Isolation of a novel catechin from Bergenia rhizomes that has pronounced lipase-inhibiting and antioxidative properties. Fitoterapia, 82: 212-218.

Kanski, J.; Aksenova, M.; Stoynaya, A.; Butterfield, D. A. 2002. Ferulic acid antioxidant protection against hydroxyl and peroxyl radical oxidation in synaptosomal and neuronal cell culture systems in vitro: structure-activity studies. Journal of Nutritional Biochemistry, 13: 273-281.

Kawanishi, K.; Uhara, Y.; Hashimoto, Y. 1985. Alkaloids from the hallucinogenic plant Virola sebifera. Phytochemistry, 24: 1373-1375.
Konya, K.; Vargas, Z.; Antunus, S. 2001. Antioxidant properties of 8.O.4'-neolignans. Phytomedicine, 8: 454-459.

Koolen, H.H.F.; Soares, E.R.; da Silva, F.M.A.; de Souza, A.Q.L.; Rodrigues-Filho, E.; de Souza, A.D.L. 2012. Triterpenes and flavonoids from the roots of Mauritia flexuosa. Revista Brasileira de Farmacognosia, 22: 189-192.

Pereira, A.C.H.; Lenz, D.; Nogueira, B.V.; Scherer, R.; Andrade, T.U.; Costa, H.B.; et al. 2016. Gastroprotective activity of the resin from Virola oleifera. Pharmaceutical Biology, 55: 472-480.

Rezende, K. R.; Kato, M. J. 2002. Dibenzylbutane and aryltetralone lignans from seeds of Virola sebifera. Phytochemistry, 61: 427-432.

Rezende, K.R.; Davino, S.C.; Barros, SBM.; Kato, M.J. 2005. Antioxidant activity of aryltetralone lignans and derivatives from Virola sebifera (Aubl.). Natural Product Research, 19: 662- 666

Riba- Hernández, P.; Segura, J.L.; Fuchs, J.E.; Moreira, J. 2014. Population and genetic structure of two dioecious timber species Virola surinamensis and Virola koschnyi (Myristicaceae) in southwestern Costa Rica. Forest Ecology and Management, 323: 168-176.

Rodrigues, W.A. 1980. Revisão Taxonômica das Espécies de Virola Aublet (Myristicacea) do Brasil. Acta Amazonica, 10: 3-127.

Stecanella, L.A.; Taveira, S.F.; Marreto, R.N.; Valadares, M.C.; Vieira, M.S.; Kato, M.J.; Lima, E.M.; et al. 2012. Development and caracterization of PLGA nanocapsules of grandisin isolated from Virola surinamensis: In vitro release and cytotoxicity studies. Revista Brasileira de Farmacognosia, 23: 153-159.

Souza, M.P.; Bataglion, G.A.; da Silva, F.M.A.; de Almeida, R.A.; Paz, W.H.P.; Nobre, T.A.; et al. 2016. Phenolic and aroma compositions of pitomba fruit (Talisia esculenta Radlk.) assessed by LC-MS/MS and HS-SPME/GC-MS. Food Research International, 83: 87-94.

Valderrama, J.C.M. 2000. Distribution of flavonoids in the Myristicaceae. Phytochemistry, 55: 505-511.

Veiga, A.; Albuquerque, K.; Côrrea, M.E.; Brigido, Helliton.; Silva, J.S.; Campos, M.; Silveira, F. et al. 2017. Leishmania amazonensis and Leishmania chagasi: In vitro leishmanicide activity of Virola surinamensis (rol.) Warb. Experimental Parasitology, 175: 68-73.

RECEIVED: 05/03/2018

ACCEPTED: 19/08/2018

ASSOCIATE EDITOR: Jorge David 